\title{
Financing Constraints and the Short-Run Response to Fiscal Policy
}

\author{
LAURENCE H. MEYER
}

M

ONETARISTS have long emphasized that the impact of an increase in government expenditures depends on how the increase is financed. In particular, they have suggested that a bond-financed increase in government expenditures has only minimal effects on aggregate demand and income, because the government borrowing necessary to finance the additional public expenditures may "crowd out" a roughly equivalent amount of private spending and borrowing. This view is summarized as follows:

"Fiscal policy provides additional spending in a world of sparse spending opportumities. But it does not provide a new soluce of finance in a world where spending is constrained by sources of finance. The government expenditures are financed in debt markets in competition with private expenditures. The case least favorable to fiscal policy is that in which the additional government borrowing simply crowds out of the market an equal (or conceivably even greater) volume of borrowing that would have financed private expenditures."

This paper presents a framework for analyzing fiscal policy that incorporates the interaction between govemment and the private sector in their spending and borrowing decisions. It shows that ambiguity surrounding the income-multiplier for increased government expenditures results from the failure to model correctly the stock repercussions of changes in govemment spending and private investment. Specifically, the ambiguity is caused by failure to allow for changes in the supply of capital (or private financial securities issued to finance the capital stock) that arise in

IJohn M. Culbertson, Macroeconomic Theory and Stabilization Policy (New York: McGraw-Hill, 1968), p. 463. response to debt-financed fiscal policy. When the analysis is amended to correctly incorporate the financing of private and public expenditures and to develop the relationship among saving, the deficit, and crowding out, the initial impact of an increase in government expenditure on aggregate demand and income is unambiguously positive.

\section{FOUR MODELS OF THE SHORT.RUN RESPONSE TO FISCAL POLICY}

Four models of the response to fiscal policy are analyzed in detail. Each model includes the equilibrium conditions in the commodity and money markets (which correspond to the IS and LM curves in standard income-expenditure analysis) and the definition of disposable income, as shown in equations (1) through (3). The demand for output depends on income and the interest rate [equation (1)]; the money supply is exogenous, and the demand for money depends on the interest rate, income, and end-of-period value of household wealth [equation (2)].2 Disposable income is simply national income minus taxes net of transfers [equation (3)].

\footnotetext{
The model inchudes a wealth effect in the money demaxd function but not in the consumption function. This was done primarily to simplify the analysis, since the major concern involves the portfolio effects of fiscal policy. In addition, the relevant wealth variable in a consumption function is beginning of period wealth, and this is predetermined in the subsequent analysis. "The only way a weath effect in the conm sumption function conld affect the conclusions is through an interest-induced wealth effect. Ineluding an interest-induced wealth effect would be equivalent to making consumption (saving) depend on the interest rate. Such a modification is discussed later in the analysis.
} 
Models 1-4

$$
\begin{aligned}
& \begin{array}{l}
\text { Model I: } \\
\quad 1-3 \\
\text { with } \mathrm{L}_{\mathrm{a}}=0
\end{array} \quad\left\{\begin{array}{l}
\text { (1) } \mathrm{X}=\mathrm{C}_{\mathrm{y}} \mathrm{Y}+\mathrm{I}_{\mathrm{r}} \mathrm{r}+\overline{\mathrm{C}}+\mathrm{I}+\overline{\mathrm{G}} \\
(2) \mathrm{M}=\overline{\mathrm{M}}+\mathrm{L}_{\mathrm{s}} \mathrm{X}+\mathrm{L}_{\mathrm{r}} \mathrm{r}+\mathrm{I}_{\mathrm{a}} \mathrm{a} \\
\text { (3) } \mathrm{Y}=\mathrm{X}-\overline{\mathrm{T}}
\end{array}\right. \\
& \text { Model II: } \quad \quad \quad(4) a=\bar{m}+\mathrm{b}+\overline{\mathrm{K}} \\
& 1-3+4,5 \\
& \text { Model III: } \\
& 1-3,5-7 \\
& \left\{(5) \Delta \mathrm{b}=\mathrm{D}_{-1}+\Delta \overline{\mathrm{G}}-\Delta \overline{\mathrm{T}}-\Delta \overline{\mathrm{m}}\right. \\
& \{\text { (6) } \mathrm{a}=\overline{\mathbf{m}}+\mathrm{b}+\mathrm{d} \\
& \text { (7) } \Delta \mathrm{d}=\mathrm{I}_{-1}+\Delta I=\mathrm{I}_{-1}+\mathrm{I}_{\mathrm{r}} \Delta \mathrm{r} \\
& \text { Model IV: } \quad\{(8) \text { a }=a+a+S \\
& 1-3,8,9 \quad\left\{\text { (9) } \mathrm{S}=\mathrm{Y}-\mathrm{C}=\mathrm{Y}-\left(\overline{\mathrm{C}}+\mathrm{C}_{\bar{F}} \mathrm{Y}\right)\right.
\end{aligned}
$$

\section{Notation:}

Parameter restrictions:

$$
\begin{aligned}
& 1>\mathrm{C}_{y}>0 \\
& -\infty<\mathrm{I}_{\mathrm{F}}<0 \\
& \mathrm{~L}_{\mathrm{x}}>0 \\
& -\infty<\mathrm{I}_{\mathrm{F}}<0 \\
& 1>\mathrm{L}_{\mathrm{H}}>0
\end{aligned}
$$

Model I, the traditional textbook model associated with the income expenditure view, assumes $L_{t: 1}=0$ and includes only equations (1) through (3). It also corresponds, however, to Friedman's representation of a common framework that would be acceptable to both monetarists and nommonetarists. ${ }^{3}$

\section{Alternative Approaches to Modeling Wealth Determination}

Models 2 through 4 include the determination of household wealth, and it is the modeling of wealth See, for example, Milton Friedman, "A Theoretical Frame-
work for Monetary Analysis," Joumal of Political Economy (March/April 1970), pp. 193-238. that is critical to the analysis in this article. Two definitions of wealth can be used to complete the model: Both are equally correct and yield identical results when the definitions are specified propery. The sum of the assets measure defines wealth as the sum of the assets that are held in household portfolios. The perpetual inventory measure defines wealth as the sum of last period's wealth and saving, where saving is measured as the change in wealth between last period and this period." The sum of the assets approach links wealth to the rest of the model by using financing constraints that link the supply of money and bonds to spending decisions of the govermment and private sectors. The perpetual inventory approach links weatth to the rest of the model by adding a saving equation to the model.

Model 2 is an extension of Model 1 and incorpo rates both a wealth effect in the demand for money $\left(0<\mathrm{L}_{k}<1\right.$ ) and a government financing constraint [equation (5)]. The government financing constraint (GFC) requires that govemment expenditures ( $G$ ) be financed by some combination of taxes net of transfers ( $T$ ) and issue of money and government bonds ( $\Delta \mathrm{m}$ and $\Delta \mathrm{b}$, respectively) ${ }^{5}$ Fquation (5) rewrites this restriction in terms of the inherited deficit $\left(D_{-1}\right)$ and changes in government expenditures and taxes $(\triangle \mathrm{G}$ and $\Delta \mathrm{T}$, respectively). The inherited deficit plus any increase in govermment spending in the present period relative to the previous period must be financed by increases in tax revenue net of transfers or by issue of money or government bonds.

Wealth is defined, according to equation (4), as the sum of money, government bonds, and the capital stock. Both money and the capital stock are assumed to be constant, and the supply of government bonds is determined via the GFC. Since all four models assume an exogenous money supply, increases in gov-

4Peter $\mathrm{E}$. Kennedy, "Direct Wealth Effects in Macroeconomics Models: The Saving vs. the Definitional Approach," Jounal of Money, Credit and Banking (February 1978), pp. 94.8.

5The integration of the government financing constrains into macroecononic models was advanced by the work of Carl Christ. See for example, Carl F. Christ, "A Simple Macroeconomic Model with a Covernment Budget Constratint, Journal of Political Economy (Jamary/February 1968), pp. 53-67.

the atthor assumes throughout that government bonds are part of net wealth and this assumption presumes the absence of "tax discounting." The evidence on tax discounting is mixed. For a review of the theory and evidence on tax discounting, see Willem H. Buiter and James Tobin, "Debt Neutralify: A Brief Review of Doctrine and Evidence," Cowles Foundation Discussion Paper No. 497 (Yale University, September 15, 1978). For an empirical investigation which finds no evidence of tax discounting, see Jess B. Yawitz and Laurence H. Meyer, "An Enpirical Investigation of the Extent of Tax Discount" ing," Journal of Money, Credit and Banking (May 1976), pp. $247-56$. 
ernment expenditures are financed by increasing the government debt. This common assumption allows us to focus on debt-financed fiscal policy.

The critical assumption in Model 2 is that the capital stock is also exogenous. Although this assumption is common in short-run models of income determination, it presents serious difficulties for modeling the portfolio repercussions of fiscal actions. ${ }^{7}$

Models 3 and 4 further refine the analysis of fiscal policy by relaxing the assumption that the capital stock is fixed. These models introduce properly specified but alternative definitions of wealth. Model 3 essentially retains the wealth definition used in Model 2 but endogenizes the capital stock by defining the end-of-period capital stock as the sum of the beginning-of-period capital stock and investment over the period. All capital is assumed to be held by firms and purchased with extemal funds acquired by selling securities to the household sector. Thus, households can be viewed as indirectly holding the capital stock via their holdings of private securities, and the net wealth of the household sector can be rewritten as the sum of money, government bonds, and private securities [equation (6)], where the supply of private securities is determined via the investment financing constraint [equation (7)]. ${ }^{8}$ The simple structure of the model can be maintained by assuming that government debt and private securities are perfect substitutes in household portfolios. ${ }^{9}$ The supply of private securities is determined by the investment financing constraint (IFC), the private sector counterpart to the GFC. The IFC [equation (7)] links changes in the supply of private securities directly to (net) investment (expressed as last period's investment plus the change in investment from last period to the current period) and thus links private spending and financial decisions.

\footnotetext{
"Models embodying the assumption of a fixed capital stock have been used to investigate the portfolio repercussions of fisca policy by Silber, Meyer, and B. Friedman, See William L, Silber, "Fiscal Policy in IS-LM Analysis: A Correction," Journal of Money, Credit and Banking (November 1970), pp. 461-72; Laurence H. Meyer, "The Balance Sheet Identity, the Govermment Financing Constraint, and the Crowding-Out Effect, Joumal of Monetary Economics (January 1975), pp. 65-78; and Benjamin Friedman, "Crowding-Ont or CrowdingIn: Fconomic Consequences of Financing Government Defcits," Brookings Papers on Economic Activity (1978:3), pp. $593-641$.

8Equations (4) and (6) correspond to two different ways of defining wealth: net private wealth and net wealth of households. Net private weanth equals the captal stock (the economy's taugible or real assets) plus ontside fnancial assets of the private sector (outside money and government bonds) Net wealth of households includes only the outside financial. assets of the hotsehoud sector (assuming all capital assets are held by businesses). The two are identical, provided capital in net private weath is valued at its market value as defined by the value of the financial claims to that capital stock held in household portfolios.

FFirms finance acquisition of capifal via private bonds, equities,
}

\section{Propenties of the Tramework}

These four models have a common framework: They are fixed price/variable output, one-good, twoasset models of the short-run response to fiscal policy. Additionally, Models 3 and 4 employ an end-of-period specification of asset market equilibrium.

The fixed price/variable output framework is appropriate for studying the response of output to policy actions in a disequilibrium setting where price flexibility is insufficient to sustain continuous full equilibrium. ${ }^{\text {io }}$ Its suitability, however, is confined to developing insights about the short-run response to fiscal actions.

The framework described in this article extends the one-good, two-asset IS/LM model that is widely used in macroeconomics. The two assets included in the models are money and bonds. Both government and private debt are included in Models 3 and 4 and, in order to retain the two-asset framework, they are assumed to be perfect substitutes in household portfolios. To further simplify the analysis, households are assumed to hold all the financial assets and, in Models 3 and 4 , firms are assumed to finance all investment externally.

The models are developed to yield one-period multipliers only. Models 2, 3, and 4 are intrinsically dy. namic since the supply of bonds continues to increase as long as the government runs a deficit and, in Models 3 and 4 , as long as saving and investment occur. The $\mathrm{GFC}$, for example, requires that government expenditure increases be financed not only in the initial period but during all future periods as long as the deficit continues. The models, however, investigate the impact of the increase in govermment spending during the initial period only.

To model the financial repercussions of spending decisions in a one-period framework, an end-of-period (EOP) specification of asset market equilibrium is

and internal funds. To maintain the model's simple structure and allow every possibility for substantial portfolio effects associated with government deficits, all investment is assumed to be financed extemally by emitting a single financial instrument which is a perfect substitute for government bonds in wealth owners portfolios. In principle, the models employed in this article should distinguish between private debt equity, and government debt. But the approach used here only makes the portfolio effect of deficit financing larger and the concluston 走hat there is an unambiguous one-period multiplier more noteworthy. For a three-asset version that is otherwise simitar to the approach taken in this paper, see James Tobir and $W_{i}$. lem Buiter, "Fiscal and Monetary Policies, Capital Formation, and Economic Activity," in George von Furstenburg, ed. The Government and Capital Formation (Cambridge: Ballinger Publishing Co., 1980), pp. 73-151.

10 For a rationalization of this approach, see Robert J. Barro and Herschel I. Grossman, Money, Employment, and Inflation (Cambridge: Cambridge University Press, 1976). 
used in Models 3 and $4 .^{11}$ In discrete time models, the concept of simultaneous equilibrium in stock and flow markets is subtle. Since flows are defined as rates over the unit interval and stocks are defined at a point during the interval, there is no natural way of defining simultaneous equilibrium. ${ }^{12}$ For the following analysis, it is convenient to define simultaneous equilibrium as corresponding to flow equilibrium over the period and to stock equilibrium at the end of the period. By defining stocks at the end of the interval used to define the flow variables, the financing of expenditure flows over the period is allowed to affect the supplies of bonds outstanding, thereby allowing the model to include both the effect of the increase in expenditures and the effect of the associated increase in the supply of bonds.

\section{MODEL 1: THE TEXTBOOK MULTIPLIER AND HICKSIAN CROWDING OUT}

The textbook IS/LM multiplier identifies a single source of crowding out, labeled by Modigliani and Ando as "Hicksian crowding out."13 Model 1 includes neither a wealth effect in the demand for money $\left(\mathrm{L}_{\mathrm{a}}=0\right.$ ) nor any financing constraints. It is generally associated with the income-expenditure approach and has been widely criticized by monetarists. The multiplier for an increase in government expenditures in

11 For a discussion of the modeling of simultaneous stock and flow equilibria in period models, see Duncan K. Foley, "Ori Two Specifications of Asset Equilibrium in Macroeconomic Models" The Journal of Political Economy (April 1975), pp. 303-24.

120 ne way to eliminate the ambiguity is to reduce the unit interval of the period analysis until the beginning and the end of the period converge. This results in a continnous analysis in which flows at instantaneous rates and stocks can both be measured simultaneously. However, since this analysis focuses on capturing the stock repercussions of flow decisions, the end-of-period, discrete framework is particularly appropriate. Most continuous models are used to solve for either instantaneous on steady-state values of multipliers. Discrete models, on the other hand, are the most convenient approach when the analysis is to be carried ont over a discrete interval, short of the time required to achieve full steady-state equilibrium. For example, Turnovsky notes: "While many macroeconomic models are formulated using discrete time, much of macroeconomic theory is formulated using continuous time. Both kinds of models have their place, and the choice between them is often dictated by convenience. If one is interested in analyzing short-run effects, discrete time models tend to be more useful. On the other hand, for steady-state and stability analyses, continuous models are usually more practical. Stephen I. Turnovsky, Macroeconomic Analysis and Stabilization Policies (Cambridge: Cambridge University Press, 1977), p. 43 .

13 Franco Modigliani and Albert Ando, "Impacts of Fiscal Actions on Aggregate Income and the Monetarist Controversy: Theory and Evidence," in Jerome Stein, ed. Monetarism (Arasterdam: North-Holland Publishing Company, 1976), pp. 17 42. The terminology "Hicksian crowding-out," reflects the origins of the IS-LM framework in the writing of I. R, Hicks. See, for example, J. R. Hicks, "Mr. Keynes and the Classics: A Suggested Interpretation," Econometrica (April 1937), pp. 145.59. this model is:

$$
\text { (1) } \frac{\Delta \mathrm{X}}{\Delta \mathrm{G}}=\frac{1}{1-\mathrm{C}_{\mathrm{F}}+\underbrace{\left(\mathrm{I}_{\mathrm{r}} / \mathrm{L}_{\mathrm{r}}\right) \mathrm{I}_{\mathrm{T}}}_{\text {Hickstan crowding out }}}
$$

This multiplier has several properties: (1) In the absence of extreme values of the parameters, the multiplier is unambiguously positive, confirming the income expenditure view about the response to fiscal policy. (2) The multiplier does not allow for any effect of government borrowing on the response of output to the fiscal operation. Since money and taxes are held constant, the multiplier implicitly corresponds to a bond-financed fiscal action. Despite the absence of any effect associated with the increase in government borrowing, partial crowding out occurs via the in come-induced rise in the interest rate. As income increases, the demand for money increases relative to the fixed supply of money. The resulting excess demand for money (and excess supply of bonds) exerts upward pressure on the interest rate which, in turn, restricts the interest responsive portion of aggregate demand (investment, in this model). However, as long as $\mathrm{L}_{\mathrm{r}}<0$ and $\mathrm{I}_{\mathrm{r}}>-\infty, \Delta \mathrm{X} / \Delta \mathrm{G}$ remains positive and investment declines by less than the increase in government expenditures. The magnitude of Hicksian crowding out (or negative feedback) is controlled by the last set of terms in the denominator of equation (1).

Thus, although some investment is crowded out by government spending, the fiscal multiplier is nevertheless unambiguously positive. Of course, this does not guarantee that the multiplier is large. Monetarists have generally argued that, even in this framework, fiscal policy will have a minimal effect due to the actual magnitude of Hicksian crowding out resulting from the small absolute value of the $L_{\mathrm{r}}$ parameter and the large absolute value of the $I_{r}$ parameter. ${ }^{14}$

\section{MODEL 2: THE GRC AND THE WEALTH EFFECT: PORTFOLIO CROWDING OUT AND THE AMBIGUOUS FISGAL MULTIPLTER}

To generate an ambiguous sign on the fiscal multiplier in this framework, the financing of government spending via the increase in the supply of government bonds must affect the interest rate and income. This requires that a wealth effect be added to the demand for money $\left(1>L_{a}>0\right)$ and that both the definition of wealth given by equation (4) and the GFC [equation (5)] be included in the analysis. 14Se, for example, Milton Friedman, "Comments on the
Critics," Joumal of Political Economy (September/October 1972), pp. $906-50$ 
The resulting fiscal multiplier is:

$$
\text { (2) } \frac{\Delta \mathrm{X}}{\Delta \mathrm{Q}}=\frac{1-\overbrace{\left(\mathrm{L}_{\mathrm{a}} / \mathrm{L}_{\mathrm{r}}\right) \mathrm{I}_{\mathrm{r}}}^{\begin{array}{c}
\text { pottfotio } \\
\mathrm{erowding}
\end{array}}}{\mathrm{Q}}
$$

where the denominator, $Q$, is the same as in the first multiplier. The fiscal operation now has two direct impacts, indicated by the two terms in the numerator of equation (2): The increase in $G$ directly increases aggregate demand (the direct fiscal impact, also operative in Model 1) and the accompanying increase in the supply of bonds exerts upward pressure on interest rates, thereby reducing aggregate demand (the direct portfolio impact). The net effect of these two direct impacts - and, hence, the multiplier - is ambiguons. Thus, while Hicksian crowding out can, at most, induce partial crowding out, "portfolio crowding out" can, at least in this model, induce complete or even more than complete crowding out, as suggested by the quote at the beginning of this article.

Note that if $\mathrm{L}_{\mathrm{a}}=0$, the multiplier collapses to the multiplier derived for Model 1 . Income-expenditure, macroeconometric models typically use a transactionsbased model of the demand for money (where $\mathrm{L}_{2}=$ 0 ), while monetarists generally prefer portfolio models of the demand for money (where $L_{a}>0$ ). If $L_{a}=0$, wealth owners want to retain the entire increment in wealth in the form of bonds; in this case, the increase in the supply of bonds does not induce an excess supply of bonds and, therefore, does not exert upward pressure on the interest rate. On the other hand, if $\mathrm{L}_{\mathrm{a}}>0$, wealth owners want to diversify their portfolios and, hence, to split any increase in wealth between increased holdings of money and bonds. In this case, an increase in the supply of bonds and wealth will increase the demand for bonds by less than the increase in the supply of bonds, resulting in an excess supply of bonds and upward pressure on the interest rate.

\section{MODEL 3: ADDING THE INVESTMENT FINANCING CONSTRAINT: RETURNING TO AN UNAMBIGUOUS MULTIPLIER}

Models 1 and 2 are useful as simple models which yield income-expenditure and monetarist results, respectively, but both are incomplete. Models 3 and 4 refine the analysis presented in Models 1 and 2 in different but equivalent ways. Although each combines portfolio crowding out with Hicksian crowding out as did Model 2, they yield unambiguously positive fiscal multipliers as did Model 1.
In order to allow for portfolio crowding out, it is necessary to continue assuming that $1>\mathrm{L}_{\mathrm{a}}>0$. The problem with Model 2 is that it accounts for the financing of government spending but ignores the financial repercussions of private spending. Model 3, therefore, respecifies the definition of wealth to include private securities along with government debt, and the IFC is added in order to link investment to the supply of private securities. Thus, Model $3 \mathrm{in}$ cludes dual financing constraints: End-of-period wealth is now the sum of end-of-period supplies of money and bonds, and the GFC and IFC are used to determine end-of-period supplies of government and private securities, respectively.

By redefining wealth, Model 3 refines the definition given in Model 2, where the capital stock was treated as fixed even though net investment was occurring. Consequently, Model 2 failed to address the portfolio repercussions of investment. Increases in the capital stock associated with investment must be absorbed into private portfolios, just as increases in government debt associated with government deficits must be absorbed.

The multiplier for Model 3 is:

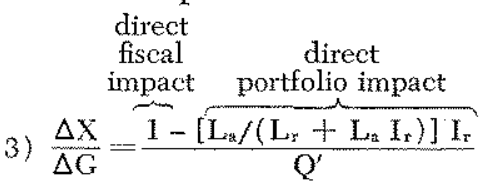

where $Q^{\prime}=1-\mathrm{C}_{\mathrm{r}}+\left[\mathrm{L}_{\mathrm{x}} /\left(\mathrm{L}_{\mathrm{r}}+\mathrm{L}_{\mathrm{a}} \mathrm{I}_{\mathrm{r}}\right)\right] \mathrm{I}_{\mathrm{r}}$. The two terms in the numerator reflect the two direct impacts associated with the fiscal operation. The direct fiscal impact is the dollar-for-dollar increase in aggregate demand associated with the increased government expenditure. The direct portfolio impact is the effect on investment associated with the increase in the sup ply of government bonds. The multiplier has a form similar to that of Model 2: A positive direct fiscal impact and negative portfolio impact are contained in the numerator. However, in the case of Model 3, it can be demonstrated that the direct portfolio impact is unambiguously smaller than the direct fiscal impact so that the multiplier is unambiguously positive. The numerator is positive because the terms in the direct portfolio impact can be combined to form a ratio less than unity $\left[\mathrm{L}_{\mathrm{a}} \mathrm{I}_{\mathrm{r}} /\left(\mathrm{L}_{\mathrm{r}}+\mathrm{L}_{\mathrm{x}} \mathrm{I}_{\mathrm{r}}\right)<1\right]$.

The multiplier given by Model 3 implies that, although investment declines in response to an increase in government spending, the decline in investment induced by the increase in supply of government bonds is less than the increase in government expenditures. The increase in government debt raises the interest rate because it results in an increase in the supply 
relative to the demand for bonds. If the decline in investment due to the rise in the interest rate were to exceed the increase in government spending, the decline in private bonds (associated with the decline in investment) would exceed the increase in the supply of government bonds so that the total supply of bonds would fall rather than rise. ${ }^{15}$ This situation, of course, would be contradictory since investment declines only if the interest rate rises. Because the decline in investment slows the rise in the interest rate, the resulting portfolio crowding out can be only partial. Although Hicksian crowding out occurs in tesponse to the rise in income, it cannot alter the conclusion that the fiscal policy multiplier is unambiguously positive.

\section{MODEL 4; A SIMPLIFIED SOLUTION WITH THE PERPETUAL INVENTORY DEFINITION OF WEALTH}

Model 4 underlies Modigliani and Ando's conchlsion that the short-run response to fiscal policy is positive: "Clearly $\mathbf{r}$ camnot rise unless [a] rises; but [a] cannot rise unless saving increases, which requires a rise in X!"16 Model 4 uses a perpetual inventory definition of wealth [equation (8)] that is equivalent but altemative to that employed in Model 3. End-ofperiod wealth is defined in this case as beginning-ofperiod wealth plus saving over the period. ${ }^{17}$ The $\Delta X$ $\Delta \mathrm{G}$ multiplier for this model is:

$$
\text { (4) } \frac{\Delta \mathrm{X}}{\Delta \mathrm{G}}=\frac{1}{1-\mathrm{C}_{5}+1 \underbrace{\left.\left(\mathrm{L}_{\mathrm{x}}+\mathrm{L}_{\mathrm{a}}\left(1-\mathrm{C}_{F}\right)\right) / \mathrm{L}_{r}\right] \mathrm{I}_{r}}_{\text {both Hicksian and portfolio crowding out }}}
$$

This multiplier, like that for Models 2 and 3 , includes both Hicksian and portfolio crowding out and it is identical to that in Model 3 even if it doesn't appear to be ${ }^{18}$ As in Model 3, portfolio crowding out can be only partial.

15The statement that a decline in investment induces a decline in the supply of private bonds requires clarification. As long as net investment is positive, the supply of bonds will be increasing. The bond financing of government expenditures raises the interest rate, lowers investment, and lowers the supply of bonds relative to what it wauld have been in the absence of the policy action. The multiplier $\Delta \mathrm{X} / \Delta \mathrm{G}$, in turn, indicates how income differs from what it wonld have been in the absence of the policy action. The multiplier, therefore, has a different interpretation than the usual comparative static multipliers derived from IS/LM modes without financing constraints. Such multipliers indicate the change in income between the old and the new equilibrium levels of income. One-period multipliers in models with financing constraints, in contrast, only indicate how income differs from what it would have been in the absence of the policy change.

16Modigliani and Ando, "Impacts of Fiscal Actions on Aggregate Income and the Monetarist Controversy," p. 17

17Capital gains have been ignored in order to simplify the analysis.

${ }^{18}$ To show that Models 3 and 4 are identical, put the numerator of equation (3) in terms of a common denominator,
Multiplier 4 resembles multiplier 1 but it contains an additional term in the numerator of the fraction in the denominator of the multiplier. This term, $\mathrm{L}_{\mathrm{a}}\left(1-\mathrm{C}_{y}\right)$, represents the effect of the increase in wealth (via saving) on the demand for money. Since the money supply remains unchanged, all additional wealth is implicitly held in the form of bonds. To induce the private sector to increase its holdings of bonds relative to money, the Treasury must offer a higher interest rate. But, as Modigliani and Ando have noted, portfolio crowding out is activated by the increase in wealth that is associated with an increase in saving and, hence, income. ${ }^{19}$ Therefore, portfolio crowding out can restrain but not reverse the increase in income associated with the increase in government spending.

Model 4 highlights the role of saving in the analysis of crowding out. The increase in government bonds can be absorbed into private portfolios either by an increase in wealth (i.e., induced saving generated by the fiscal action) or by displacing (i.e., crowding out) private debt. Saving can be defined as the sum of the deficit and investment; the deficit can be defined as the difference between saving and investment. Any increase in the deficit must be offset, therefore, by a combination of increased saving (allowing absorption of increased government bonds) or decreased investment (replacing private securities with govemment bonds).

Model 4 analyzes the response to fiscal actions without directly including either the GFC or the IFC. Models 2 and 3 include the financing constraint in order to determine the end-of-period supplies of govermment and private bonds. The bond market is the redundant market in the analysis, and the perpetual inventory definition of wealth does not use end-ofperiod supplies of bonds. Consequently, Model 4 does not explicitly contain the supply of bonds or require the financing constraints in order to solve for the response to fiscal actions.

\section{REFINEMENTS AND COMPLICATIONS}

This section discusses the implications of relaxing

$\mathrm{L}_{\mathrm{r}}+\mathrm{L}_{a} \mathrm{I}_{\mathrm{F}}$; then multiply the numerator and denominator by $L_{r}+L_{\mu} I_{r}$; then divide the numerator and denominator by $L_{r}$. The equivalence of Models 3 and 4 can also be seen by comparing the two defintions of wealth: Model 3 defines the change in wealth as the sum of the deficit and investment, and Model 4 defines the change in wealth as equal to saving. Since $S=I+D$ is an equilibrium condition, the multipliers for Models 3 and 4 will be idextica!

197he "inctease in wealth" in the above statement refers to the increase in wealth relative to what it would have been in the absence of the policy action. As long as saving is positive, wealth will increase. The policy action induces an increase in wealth only if it induces an increase in saving. 
some of the assumptions employed in Models 1 through 4. First, some considerations relevant to an analysis of the longer-run response to fiscal actions are discussed. Second, two modifications that introduce the possibility that bond-financed fiseal policy may "pull in" rather than crowd out investment are considered. Finally, a modification that allows for an ambiguous short-run fiscal multiplier in Models 3 and 4 is discussed.

\section{Longer-Run Considerations: Price Flexibility and Cumulative Stock Effects}

Models 1 through 4 yielded only one-period multipliers. The longer-run response to fiscal actions is affected also by price flexibility and the cumulative effects of financing continuing deficits associated with once-and-for-all changes in government expenditures.

The models employed above assumed prices were fixed and were justified as simple disequilibrium models along lines developed by Barro and Grossman. However, they apply only to the analysis of the shortrun response to fiscal actions. In the long run, price flexibility insures a unique equilibrium level of the unemployment rate via the Phillips Curve. Although fiscal policy may temporarily increase output and employment, most models yield zero long-run multipliers for the response of output and employment to policy actions. ${ }^{20}$

Another factor that affects the longer-run response to fiscal actions is the continuing increase in the supply of bonds associated with a once-and-for-all increase in government expenditures. The implications of the continued financing of deficits associated with once-and-for-all increases in government expenditures for the long-run response of income have been investigated by Blinder and Solow. ${ }^{2 \mathrm{t}}$

\section{Pulling In: Income-Induced Investment and Multiple Assets}

In each of the models developed above, an increase in government expenditures reduced investment. The question they addressed was whether investment fell by more or less than the increase in government expenditures. Two simple modifications introduce the

\footnotetext{
20See, for example, Modigliani and Ando's discussion of policy sirnulations with the MPS model in "Impacts of Fiscal Actions on Aggregate Income and the Monetarist Controversy."

${ }^{21}$ Alan S. Blinder and Robert M. Solow, "Does Fiscal Policy Matter?" Joumal of Public Economics (November 1973), pp. 319-37.
}

possibility that bond-financed increases in government expenditures may encourage rather than discourage investment. These modifications include adding income as an argument in the investment function and allowing government debt and private securities to be imperfect substitutes.

If investment depends on the level of income, investment may rise even though the fiscal operation raises the interest rate. Hendershott has referred to this phenomenon as pulling in rather than crowding out investment. ${ }^{22}$

In the two-asset model employed above, increased supply of government debt restrains investment, in part, because government and private securities are assumed to be perfect substitutes. If the model is refined to allow for at least three assets - money, government debt, and, for example, equities - the portfolio response to the increase in the supply of government debt becomes ambiguous. Tobin and Tobin and Buiter have used three-asset models to study the response to policy actions. ${ }^{23}$ In the twomasset model, an increase in government debt creates excess supply in the securities market and upward pressure on "the" interest rate. The three-asset model involves two rates: The rate on government bonds and the rate on equities. The models generally focus on the rate on government debt and the price of equities, and they designate investment as a positive function of the price of equities.

An increase in government debt increases the rate on government bonds thereby inducing substitution out of equities into government debt. This substitution effect reduces the demand for equities and depresses their price (thus raising their rate of return). Wealth is also increasing, and wealth owners may wish to diversify their portfolios and hold some of their increased wealth in equities. This wealth effect increases the demand for equities, as well as their price. The net impact of the substitution and wealth effects is ambiguous. Equity prices and, hence, investment may rise or fall. In this three-asset example, if $\mathrm{L}_{\mathrm{a}}=0$, an increase in the supply of government debt unambiguously raises equity prices and stimulates investment.

\footnotetext{
22Patric H. Hendershot, "A Tax Cut in a Multiple Security Model: Crowding-Out, Pulling-In and the Term Structure of Interest Rates," Joumal of Finance (September 1976), pp. $1185-99$.

23 Tames Tobin, "An Essay on Principles of Debt Management," in Fiscal and Debt Management Policies, Commission on Money and Credit (Englewood Cliffs, N.J.: Prentice-Hall, 1963), pp. 143-218; and Tobin and Buiter, "Fiscal and Monetary Policies, Capital Formation, and Economic Activity."
} 


\section{Interest Responsive Saving}

There is one modification of the models that permits a negative short-run response to fiscal policy - making saving a positive function of the interest rate (and consumption a negative function of the interest rate). This modification would not alter the qualitative results of Model 1, although it would, of course, increase Hicksian crowding out and reduce fiscal multipliers. In Models 3 and 4, however, it results in a theoretically ambiguous sign on the fiscal multiplier. The explanation of the effect of this modification will be most easily understood with respect to Model 4 . In that model, the key to the unambiguous result is the positive relation between income and saving: The wealth effect in the demand for money is activated by an increase in wealth which in turn requires an increase in income. If saving depends on the interest rate as well as income, however, saving can increase even if income falls. Saving has generally been considered unresponsive to interest rates, but recent work by Boskin has revived the belief that saving may be significantly interest-responsive, although it remains

24See, for example, Michael J. Boskin, "Taxation, Saving and likely that this effect is quantitatively small. ${ }^{24}$

\section{CONCLUSION}

Increased sales of government securities necessary to finance increased government expenditures can be purchased either from the increased saving that is generated by the fiscal action or by the crowding out of private security purchases. In order to fully model the response to fiscal policy, it is essential to capture the relationships among the deficit, saving, investment, government, and private debt. This paper has developed two alternative ways of analyzing these relationships, both of which utilize end-of-period specifications of asset market equilibrium. The first approach includes both government and private sector financing constraints in the model; the second approach relates changes in wealth to saving behavior in the model. Both approaches yield positive impacts of increased government expenditures on aggregate demand and income as the first-period fiscal effect. At least in the short-run, fiscal policy actions matter because complete crowding out does not occur.

the Rate of Interest," Joumal of Political Economy (April 1978 , pp. $\$ 3-\mathrm{S} 27$

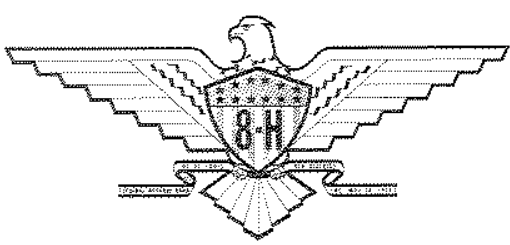

